\title{
RESPONSE OF Lantana camara var. Nana PLANTS TO FOLIAR APPLIED MALIC ACID FOR DECREASING THE HARMFUL EFFECT OF LEAD POLLUTION IN THE IRRIGATION WATER
}

(Received: 5.5.2019)

\author{
By \\ N. A. El-Shanhorey, Asma M. Taha* and M. F. Rida* \\ Botanical Gardens Research Department and ${ }^{*}$ Ornamental Plants Research Department,Antoniades \\ Horticultural Research Institute, Agricultural Research Center, Alexandria, Egypt.
}

\begin{abstract}
The present study was carried-out at Antoniades Research Branch, Horticultural Research Institute, A.R.C. Alexandria, Egypt during the two successive seasons of 2017 and 2018. The aim of the study was to evaluate the effects of irrigation water contaminated with lead on Lantana camara var. Nana plants and the possibility of using malic acid spray treatments to alleviate the effects of lead pollution. Seedlings of Lantana camara var. Nana were planted individually in plastic pots $(20 \mathrm{~cm}$ diameter) filled with $6 \mathrm{~kg}$ of mixture soil (sand and clay (1:1)). The leadcontaminated irrigation water treatments were $0,100,200$ and $300 \mathrm{ppm}$. The plants were monthly sprayed with malic acid at concentrations of 0,250 and $500 \mathrm{ppm}$. The results showed that for vegetative growth parameters there, was no significant difference in the interaction between lead concentrations and foliar spray by malic acid. While a significant reduction was observed in all parameters after irrigation with lead contaminated water, and a significant increase in vegetative growth parameters was observed after 250 ppm malic acid application. For chlorophyll and carbohydrate content, the highest significant value were obtained from plants irrigated with tap water and sprayed with $500 \mathrm{ppm}$ malic acid. While the highest significant amount of lead content in leaves, stem and roots were obtained from the treatment 300 ppm lead without application of malic acid.
\end{abstract}

Key wards: Lantana camara var.Nana, lead, malic acid.

\section{INTRODUCTION}

Lantana camara shrub is found mostly in South India, sub-tropical and tropical America and Africa. The plant named Lantana camara linn,Family: Verbenaceae, is commonly known as wild sage or red sage and lantana weed. It is a large scrambling evergreen, strong smelling shrub with stout prickles. Its leaves are opposite on both sides. Lantana flowers are small, generally orange but often vary in colors from white to dark red, which are prominently capitates in heads; bracts are conspicuous and persistent. Lantana fruits are small, $5 \mathrm{~mm}$ diameter, drupaceous and shining, blue, greenish, blackish, with two nutlets within. Lantana seeds are germinated easily throughout central and south India in most dry stony hills, and black Lantana camara is a small perennial shrub which can grow to around $2 \mathrm{~m}$ in height and forms a variety of habitats. Due to extensive selective breeding throughout the $17^{\text {th }}$ and $18^{\text {th }}$ century for use as an ornamental plant, there are now many forms of Lantana camara present throughout the world (Ashwini et al., 2014).

Plants need trace amount of heavy metal but their excessive availability may cause plant toxicity (Sharma et al., 2006). Phytotoxic concentration of the heavy metals referred in the literature does not always specify the levels (Wua et al., 2010). Lead is a toxic heavy metal that has an environmental concern (Mahler et al., 1981). There are many sources of environmental lead pollution including fuel combustion, industrial sludges, phosphate fertilizers, and mine tailings (Unhalekhana and Kositanont, 2008).

Malic acid is one of the most common low molecular weight organic acids in root exudates. Root-exuded organic acids are important mechanism in response to environment stress (Jones, 1998). Recently, many studies revealed 
that the amount of root-exuded organic acids increase under nutrient stress to increased nutrient availability (Dakora and Phillips, 2002). Malic acid is metabolized in plant mitochondria by reaction of malic enzymes, (Talebi et al., 2014). Malate is a common reserve anion playing a role in the plant vacuole as counter ion for K and Ca (Darandeh and Hadavi, 2012).

In this study Lantana camara var. Nana was chosen due to its characteristics as a non-has edible plant which can grow in tropical areas and many uses in landscaping. Therefore the objective of this study was to determine the potential of Lantana camara var. Nana in removing heavy metals from the soil affected by contaminated irrigation water.

\section{MATERIALS AND METHODS}

The present study was carried-out at Antoniades Research Branch, Horticultural Research Institute, A.R.C. Alexandria, Egypt, during the two successive seasons of 2017 and 2018. The aim of this study was to evaluate the effects of irrigation water contaminated with lead on Lantana camara var. Nana plants grown in a mixture of sand and clay $1: 1(\mathrm{v} / \mathrm{v})$, as well as, the possibility of using malic acid spray treatments to overcome the effects of lead pollution.

On the $15^{\text {th }}$ of February, in both seasons of 2017 and 2018, identical seedlings of Lantana camara var. Nana (15-20 cm height with about $10-15$ leaves) were individually planted in plastic pots $(20 \mathrm{~cm}$ diameter) filled with $6 \mathrm{~kg}$ of soil mixture (sand and clay1:1(v/v)). The chemical composition of the mixture was measured as described by Jackson (1958) and presented in Table (A).

On the $1^{\text {st }}$ of March (in both seasons), the contaminated irrigation water treatments were initiated, using concentrations of lead (II) acetate $\left(\mathrm{Pb}\left(\mathrm{CH}_{3} \mathrm{COO}\right)_{2}\right) \quad 0,100,200$ and 300 ppm. The plants were irrigated three times a week; at the end of the experiment every plant received about 85 liters cumulative amount per pot of contaminated water in Table (B). In both seasons, the plants received monthly spraying from $15^{\text {th }}$ May till $15^{\text {th }}$ August. The plants were also sprayed with malic acid at concentrations of 0,250 and $500 \mathrm{ppm}$. Control plants were sprayed with tap water. The plants were harvested on $30^{t h}$ of September in the both seasons,.

In the two seasons, all plants received NPK chemical fertilization using (Kristalon 19-19-19) at the rate of $1.5 \mathrm{~g} / \mathrm{pot}$, and it was repeated every 30 days throughout the growing season (from the $1^{\text {th }}$ of March till the $30^{\text {th }}$ of September). In addition, weeds were removed manually upon emergence.

\section{Data recorded :}

(1) Vegetative growth parameters:

Plant height $(\mathrm{cm})$, number of leaves per plant, leaves dry weight per plant $(\mathrm{g})$, leaves area $\left(\mathrm{cm}^{2}\right)$ according to Koller (1972), stem diameter $(\mathrm{cm})$, stem dry weight $(\mathrm{g})$, root length $(\mathrm{cm})$ and root dry weight (g).

(2) Chemical analysis determination:

- Total chlorophylls contents were determined as a SPAD from the fresh leaves of plants for the different treatments under the experiment at the end of the season using Minolta (chlorophyll meter) SPAD 502 according to Yadava (1986).

- Total carbohydrates percentage in the leaves was determined according to Dubios et al.(1956).

- Determination of lead content: Plant parts were individually sperated into leaves, stem and roots, then dried at $72^{\circ} \mathrm{C}$ in an oven until

Table (A): The chemical properties of the used soil mixture for the two seasons 2017 and 2018.

\begin{tabular}{|c|c|c|c|c|c|c|c|c|c|}
\hline \multirow{2}{*}{ Season } & \multirow{2}{*}{ pH } & \multirow{2}{*}{$\begin{array}{c}\text { EC } \\
\text { ds } / m\end{array}$} & \multicolumn{4}{|c|}{ Cations (meq/l) } & \multicolumn{3}{|c|}{ Anions (meq/l) } \\
\hline & & & $\mathbf{C a}^{++}$ & $\mathbf{M g}^{++}$ & $\mathbf{N a}^{+}$ & $\overline{\mathbf{K}^{+}}$ & $\mathrm{HCO}_{3}{ }^{-}$ & $\mathrm{Cl}^{-}$ & $\mathrm{SO}_{4}{ }^{--}$ \\
\hline 2017 & 8.08 & 2.53 & 18.20 & 14.20 & 23.91 & 4.49 & 7.20 & 21.00 & 27.10 \\
\hline 2018 & 8.17 & 2.35 & 18.09 & 14.11 & 23.53 & 4.38 & 7.11 & 20.75 & 25.87 \\
\hline
\end{tabular}

Table (B): The total and cumulative amount of the water used for each plant (1/pot) in each treatment during the two growing seasons of 2017 and 2018, under F.C. of $90 \%$.

\begin{tabular}{|c|c|c|c|c|c|c|c|c|}
\hline \multirow{2}{*}{$\begin{array}{c}\text { Field } \\
\text { capacity } \\
(\%)\end{array}$} & \multicolumn{10}{|c|}{ Months of growing seasons } \\
\cline { 2 - 10 } & March & April & May & June & July & August & September & Total \\
\hline $\mathbf{9 0} \%$ & 9.50 & 10.00 & 10.50 & 11.50 & 13.50 & 15.50 & 14.50 & $\mathbf{8 5 . 0 0}$ \\
\hline
\end{tabular}


constant weight. The dried plant samples were grounded. The dried samples were then digested for extraction of lead, using the method described by Piper (1947) and the concentration of lead in the samples was determined using an atomic absorption spectrophotometer.

- Available heavy metal (Lead) contents in soil samples were extracted by DPTA solution according to Lindsay and Norvell (1978) and determined by Inductively Coupled Plasma Spectrometry.

- Transfer factor (TF) is given calculated as: the ratio of the concentration lead the shoots to the concentration of lead in the soil (Chen et $a l ., 2004)$. The transfer factor is a value used in evaluation studies on the impact of routine or accidental releases of pollutant into the environment.

The experimental design was split plot with three replicates, each replicate contained three plants. The main plot was lead treatments, while the subplot was malic acid treatments. Data were subjected to analysis of variance (ANOVA) using the SAS program, (SAS Institute, 2002). The Means of the individual factors and their interactions were compared by L.S.D. test at 5\% level of probability according to Snedecor and Cochran (1989).

\subsection{Vegetative growth:}

\section{RESULTS}

\subsubsection{Plant height and leaf parameters}

Data presented in Table (1) showed that in both seasons, irrigating Lantana camara var. Nana plants with water contaminated with lead decreased the leaf parameters. Plants irrigated with the lowest lead concentration (100 ppm) had the highest mean values of plant height (32.66 and $38.58 \mathrm{~cm}$ ), number of leaves per plant (98.83 and 98.88), leaves dry weight (1.91 and $2.26 \mathrm{~g}$ ) and leaf area (472.62 and 327.29 $\mathrm{cm}^{2}$ ) in the first and the second seasons, respectively. Moreover, raising lead concentration caused steady significant reductions in leaf parameters, as the highest concentration (300 ppm) resulted significantly in the shortest plants $(29.13$ and $35.00 \mathrm{~cm})$, the least number of leaves per plant (88.22 and 88.38), leaves dry weight (1.70 and $2.05 \mathrm{~g})$ and the smallest leaves area $\left(292.66\right.$ and $\left.251.97 \mathrm{~cm}^{2}\right)$ in the first and the second seasons, respectively.

Leaf parameters were significantly affected by spraying the plants with malic acid. In both seasons, plant height of Lantana camara var. Nana increased with the treatment of malic acid it $250 \mathrm{ppm}$. Accordingly, it can be seen from the data in Table (1) that Lantana camara var. Nana plants sprayed with $250 \mathrm{ppm}$ malic acid were significantly the tallest $(31.58$ and $37.58 \mathrm{~cm})$, with the highest number of leaves per plant (95.58 and 95.99), the heaviest leaves dry weight $(1.85$ and $2.20 \mathrm{~g})$ and with the largest leaves area (412.67 and $298.99 \mathrm{~cm}^{2}$ ) in the first and the second seasons, respectively.

Regarding the interaction between the effects of irrigation with lead-contaminated water and malic acid treatments on plant height and leaves parameters of Lantana camara var. Nana plants, the results recorded in the two seasons show that, the highest values were obtained in the plants irrigated with lead at 100 ppm and sprayed with malic acid at $250 \mathrm{ppm}$ with mean values of plant height (33.33 and $39.33 \mathrm{~cm})$, number of leaves per plant $(100.83$ and 101.16), leaves dry weight per plant (1.95 and $2.31 \mathrm{~g}$ ) and leaves area per plant (546.35 and $337.41 \mathrm{~cm}^{2}$ ) in the first and second seasons, respectively. On the other hand, the shortest plants with $(28.66$ and $34.50 \mathrm{~cm})$, the lowest number of leaves per plant (86.83 and 86.66), the lowest leaves dry weight (1.67 and $2.02 \mathrm{~g}$ ) and the smallest leaves area (269.54 and 240.98 $\mathrm{cm}^{2}$ ) in the first and second seasons, respectively, were recorded when Lantana camara var. Nana plants were irrigated with lead at $(300 \mathrm{ppm})$ alone, without malic acid treatment, but in many cases, spraying the plants with malic acid reduced the undesirable effect of contaminated water with lead on these traits or parameters.

\subsubsection{Stem and root parameter}

The data recorded for the stem and root parameters of Lantana camara var. Nana plants in the two seasons (Table 2) showed that irrigation with lead-contaminated water decreased stem and root parameters, compared to that of plants irrigated with tap water (control). In both seasons, plants irrigated with tap water had the thickest stem (0.53 and 0.71 $\mathrm{cm}$ ), with the heaviest stem dry weight (3.19 and $5.20 \mathrm{~g}$ ), the longest roots $(16.82$ and $20.15 \mathrm{~cm}$ ) as well as the heaviest root dry weight (2.16 and $3.52 \mathrm{~g}$ ), respectively. On the other hand, raising lead concentration in irrigation water caused a steady reduction in stem and root parameters. This reduction was significant (compared to the 


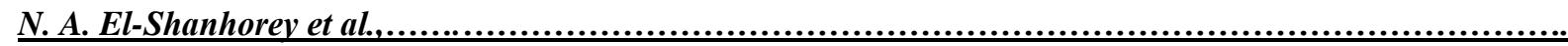

Table (1): Means of plant height (cm), number of leaves per plant, leaves dry weight (g) and leaves area $\left(\mathrm{cm}^{2}\right)$ of Lantana camara var. Nana plants as influenced by lead (Pb), Malic acid (MA) and their combinations $(\mathrm{Pb} \times \mathrm{MA})$ in the two seasons of 2017 and 2018.

\begin{tabular}{|c|c|c|c|c|c|c|c|c|c|}
\hline \multicolumn{2}{|c|}{ Treatments } & \multicolumn{2}{|c|}{$\begin{array}{l}\text { Plant height } \\
\quad(\mathbf{c m})\end{array}$} & \multicolumn{2}{|c|}{$\begin{array}{c}\text { Number of leaves } \\
\text { per plant }\end{array}$} & \multicolumn{2}{|c|}{$\begin{array}{c}\text { Leaves dry } \\
\text { weight } \\
\text { (g) }\end{array}$} & \multicolumn{2}{|c|}{ Leaves area $\left(\mathrm{cm}^{2}\right)$} \\
\hline $\begin{array}{c}\text { Lead } \\
(\mathrm{ppm})\end{array}$ & $\begin{array}{c}\text { Malic acid } \\
\quad(\mathbf{p p m})\end{array}$ & 2017 & 2018 & 2017 & 2018 & 2017 & 2018 & 2017 & 2018 \\
\hline \multirow[t]{3}{*}{ (1) } & 0 & 31.00 & 36.83 & 93.83 & 93.33 & 1.81 & 2.20 & 392.21 & 286.10 \\
\hline & 250 & 32.66 & 38.66 & 98.83 & 99.16 & 1.92 & 2.25 & 410.32 & 296.55 \\
\hline & 500 & 31.33 & 37.25 & 94.83 & 94.66 & 1.83 & 2.17 & 410.01 & 291.94 \\
\hline \multicolumn{2}{|c|}{ Mean $(\mathrm{Pb})$} & 31.66 & 37.58 & 95.83 & 95.71 & 1.85 & 2.20 & 404.18 & 291.53 \\
\hline \multirow{3}{*}{100} & 0 & 32.00 & 37.83 & 96.83 & 96.50 & 1.87 & 2.21 & 420.43 & 311.94 \\
\hline & 250 & 33.33 & 39.33 & 100.83 & 101.16 & 1.95 & 2.31 & 546.35 & 337.41 \\
\hline & 500 & 32.66 & 38.58 & 98.83 & 99.00 & 1.91 & 2.26 & 451.08 & 332.53 \\
\hline \multicolumn{2}{|c|}{ Mean $(\mathrm{Pb})$} & 32.66 & 38.58 & 98.83 & 98.88 & 1.91 & 2.26 & 472.62 & 327.29 \\
\hline \multirow{3}{*}{200} & 0 & 29.50 & 35.33 & 89.33 & 89.33 & 1.73 & 2.11 & 361.80 & 266.69 \\
\hline & 250 & 30.75 & 36.83 & 93.16 & 93.66 & 1.80 & 2.15 & 369.22 & 296.51 \\
\hline & 500 & 30.41 & 36.25 & 92.16 & 92.33 & 1.77 & 2.12 & 367.23 & 274.64 \\
\hline \multicolumn{2}{|c|}{ Mean (Pb) } & 30.22 & 36.13 & 91.55 & 91.77 & 1.76 & 2.12 & 366.08 & 279.28 \\
\hline \multirow{3}{*}{300} & 0 & 28.66 & 34.50 & 86.83 & 86.66 & 1.67 & 2.02 & 269.54 & 240.98 \\
\hline & 250 & 29.58 & 35.50 & 89.50 & 90.00 & 1.73 & 2.09 & 324.80 & 265.52 \\
\hline & 500 & 29.16 & 35.00 & 88.33 & 88.50 & 1.70 & 2.05 & 283.66 & 249.42 \\
\hline \multicolumn{2}{|c|}{ Mean $(\mathbf{P b})$} & 29.13 & 35.00 & 88.22 & 88.38 & 1.70 & 2.05 & 292.66 & 251.97 \\
\hline \multirow{3}{*}{$\begin{array}{l}\text { Mean } \\
\text { (MA) }\end{array}$} & 0 & 30.29 & 36.12 & 91.70 & 91.45 & 1.77 & 2.13 & 360.99 & 276.42 \\
\hline & 250 & 31.58 & 37.58 & 95.58 & 95.99 & 1.85 & 2.20 & 412.67 & 298.99 \\
\hline & 500 & 30.89 & 36.77 & 93.53 & 93.62 & 1.80 & 2.15 & 377.99 & 287.13 \\
\hline \multirow{3}{*}{$\begin{array}{l}\text { L.S.D. at } \\
0.05\end{array}$} & $\mathbf{P b}$ & 0.54 & 0.53 & 1.68 & 1.65 & 0.03 & 0.02 & 49.37 & 38.85 \\
\hline & MA & 0.64 & 0.65 & 1.95 & 1.88 & 0.04 & 0.04 & 26.80 & 25.96 \\
\hline & $\mathbf{P b} \times \mathbf{M A}$ & 0.74 & 0.74 & 2.25 & 2.16 & 0.04 & 0.05 & 30.80 & 29.84 \\
\hline
\end{tabular}

control), even at the highest lead concentration (300 ppm), which gave stem diameter (0.42 and $0.57 \mathrm{~cm})$, stem dry weight (2.50 and $4.01 \mathrm{~g})$, root length $(15.00$ and $18.29 \mathrm{~cm})$ and root dry weight (1.69 and $2.71 \mathrm{~g}$ ) in the first and the second seasons, respectively.

In contrast to the effect of lead treatments, malic acid treatments improved stem and root parameters of Lantana camara var. Nana plants, compared to the control. Moreover, plants sprayed with 250 ppm malic acid had significantly higher means of stem diameter $(0.48$ and $0.66 \mathrm{~cm})$, stem dry weight $(2.96$ and $4.76 \mathrm{~g})$, root length (16.27 and $19.57 \mathrm{~cm}$ ) and root dry weight (2.00 and $3.22 \mathrm{~g})$ in the first and second seasons, respectively, compared to those of control plants, or plants sprayed with any other malic acid concentration.

Regarding the interaction between the effects of irrigation with lead contaminated water and malic acid treatments on stem and root parameters of Lantana camara var. Nana plants, the results recorded in the two seasons (Table 2) showed significant differences among the values obtained from the different treatment combinations. The highest values of stem diameter $(0.58$ and $0.76 \mathrm{~cm})$, stem dry weight
(3.64 and $5.64 \mathrm{~g}$ ), root length (17.17 and 20.50 $\mathrm{cm})$ and root dry weight (2.47 and $3.82 \mathrm{~g}$ ) in the first and second seasons, respectively, were obtained in the plants irrigated with tap water and sprayed with malic acid at $250 \mathrm{ppm}$. On the other hand, the lowest values of stem diameter $(0.38$ and $0.56 \mathrm{~cm})$, stem dry weight $(2.22$ and $3.76 \mathrm{~g})$, root length (14.76 and $18.05 \mathrm{~cm})$ and root dry weight (1.51 and $2.54 \mathrm{~g}$ ) in the first and second seasons, respectively, were obtained with lead at $300 \mathrm{ppm}$ without malic acid treatment. It can also been seen from the data presented in Table (2) that in many cases, spraying the plants with malic acid alleviated the undesirable effects of lead, in irrigation water.

\subsubsection{Flowers number per plant}

Data presented in (Table 3) showed that, in both seasons, decreased with irrigation water contaminated with lead the flowers number of Lantana camara var. Nana plants. Plants irrigated with the lowest lead concentration (100 ppm) produced the highest number of flowers (19.44 and 27.05) in the first and the second seasons, respectively, but, raising lead concentration, in irrigation water caused steady significant reduction in flowers number per plant as the highest lead concentration (300ppm) 
Table (2): Means of stem diameter (cm), stem dry weight $(\mathrm{g})$, root length $(\mathrm{cm})$ and root dry weight $(\mathrm{g})$ of Lantana camara var. Nana plants as influenced by lead $(\mathrm{Pb})$, Malic acid (MA) and their combinations $(\mathrm{Pb} \times \mathrm{MA})$ in the two seasons of 2017 and 2018.

\begin{tabular}{|c|c|c|c|c|c|c|c|c|c|}
\hline \multicolumn{2}{|c|}{ Treatments } & \multicolumn{2}{|c|}{ Stem diameter $(\mathbf{c m})$} & \multicolumn{2}{|c|}{$\begin{array}{l}\text { Stem dry weight } \\
\text { (g) }\end{array}$} & \multicolumn{2}{|c|}{ Root length $(\mathrm{cm})$} & \multicolumn{2}{|c|}{$\begin{array}{c}\text { Root dry weight } \\
\text { (g) }\end{array}$} \\
\hline $\begin{array}{l}\text { Lead } \\
(\mathrm{ppm})\end{array}$ & $\begin{array}{c}\text { Malic acid } \\
\text { (ppm) }\end{array}$ & 2017 & 2018 & 2017 & 2018 & 2017 & 2018 & 2017 & 2018 \\
\hline \multirow{3}{*}{000} & 0 & 0.50 & 0.68 & 2.91 & 4.93 & 16.48 & 19.80 & 1.97 & 3.34 \\
\hline & 250 & 0.58 & 0.76 & 3.64 & 5.64 & 17.17 & 20.50 & 2.47 & 3.82 \\
\hline & 500 & 0.51 & 0.70 & 3.02 & 5.04 & 16.83 & 20.15 & 2.04 & 3.41 \\
\hline \multicolumn{2}{|l|}{ Mean $(\mathrm{Pb})$} & 0.53 & 0.71 & 3.19 & 5.20 & 16.82 & 20.15 & 2.16 & 3.52 \\
\hline \multirow{3}{*}{100} & 0 & 0.46 & 0.65 & 2.61 & 4.11 & 15.97 & 19.27 & 1.77 & 2.79 \\
\hline & 250 & 0.48 & 0.66 & 2.79 & 4.57 & 16.83 & 20.14 & 1.89 & 3.10 \\
\hline & 500 & 0.48 & 0.66 & 2.64 & 4.20 & 16.14 & 19.45 & 1.79 & 2.84 \\
\hline \multicolumn{2}{|l|}{ Mean $(\mathbf{P b})$} & 0.47 & 0.65 & 2.68 & 4.29 & 16.31 & 19.62 & 1.81 & 2.91 \\
\hline \multirow{3}{*}{200} & 0 & 0.45 & 0.63 & 2.43 & 3.79 & 15.20 & 18.49 & 1.65 & 2.57 \\
\hline & 250 & 0.46 & 0.65 & 2.71 & 4.42 & 15.84 & 19.14 & 1.84 & 3.00 \\
\hline & 500 & 0.46 & 0.65 & 2.56 & 3.97 & 15.67 & 18.97 & 1.74 & 2.69 \\
\hline \multicolumn{2}{|l|}{ Mean (Pb) } & 0.45 & 0.64 & 2.56 & 4.06 & 15.57 & 18.86 & 1.74 & 2.75 \\
\hline \multirow{3}{*}{300} & 0 & 0.38 & 0.56 & 2.22 & 3.76 & 14.76 & 18.05 & 1.51 & 2.54 \\
\hline & 250 & 0.43 & 0.58 & 2.71 & 4.42 & 15.24 & 18.53 & 1.83 & 2.99 \\
\hline & 500 & 0.45 & 0.58 & 2.58 & 3.85 & 15.02 & 18.31 & 1.75 & 2.61 \\
\hline \multicolumn{2}{|l|}{ Mean $(\mathrm{Pb})$} & 0.42 & 0.57 & 2.50 & 4.01 & 15.00 & 18.29 & 1.69 & 2.71 \\
\hline \multirow{3}{*}{ Mean (MA) } & 0 & 0.44 & 0.63 & 2.54 & 4.14 & 15.60 & 18.90 & 1.72 & 2.81 \\
\hline & 250 & 0.48 & 0.66 & 2.96 & 4.76 & 16.27 & 19.57 & 2.00 & 3.22 \\
\hline & 500 & 0.47 & 0.64 & 2.70 & 4.26 & 15.91 & 19.22 & 1.83 & 2.88 \\
\hline \multirow{3}{*}{$\begin{array}{l}\text { L.S.D. at } \\
0.05\end{array}$} & $\mathbf{P b}$ & 0.04 & 0.04 & 0.22 & 0.79 & 0.27 & 0.28 & 0.15 & 0.53 \\
\hline & MA & 0.03 & 0.02 & 0.12 & 0.44 & 0.33 & 0.34 & 0.08 & 0.29 \\
\hline & $\mathbf{P b} \times \mathbf{M A}$ & 0.03 & 0.02 & 0.14 & 0.50 & 0.38 & 0.38 & 0.09 & 0.34 \\
\hline
\end{tabular}

Table (3): Means of flower number per plant of Lantana camara var. Nana plants as influenced by lead (Pb), Malic acid (MA) and their combinations $(\mathrm{Pb} \times \mathrm{MA})$ in the two seasons of 2017 and 2018.

\begin{tabular}{|c|c|c|c|}
\hline \multicolumn{2}{|c|}{ Treatments } & \multicolumn{2}{|c|}{$\begin{array}{c}\text { Flower number per } \\
\text { plant }\end{array}$} \\
\hline $\begin{array}{l}\text { Lead } \\
(\mathrm{ppm})\end{array}$ & $\begin{array}{l}\text { Malic acid } \\
\text { (ppm) }\end{array}$ & 2017 & 2018 \\
\hline \multirow{3}{*}{000} & 0 & 19.00 & 25.83 \\
\hline & 250 & 20.00 & 27.16 \\
\hline & 500 & 19.16 & 26.00 \\
\hline \multicolumn{2}{|l|}{ Mean $(\mathbf{P b})$} & 19.38 & 26.33 \\
\hline \multirow{3}{*}{100} & 0 & 19.50 & 26.33 \\
\hline & 250 & 20.33 & 27.83 \\
\hline & 500 & 20.00 & 27.00 \\
\hline \multicolumn{2}{|l|}{ Mean $(\mathbf{P b})$} & 19.94 & 27.05 \\
\hline \multirow{3}{*}{200} & 0 & 18.00 & 24.66 \\
\hline & 250 & 18.83 & 25.50 \\
\hline & 500 & 18.66 & 25.33 \\
\hline \multicolumn{2}{|l|}{ Mean $(\mathbf{P b})$} & 18.49 & 25.16 \\
\hline \multirow{3}{*}{300} & 0 & 17.33 & 24.16 \\
\hline & 250 & 18.16 & 24.66 \\
\hline & 500 & 17.83 & 24.50 \\
\hline \multicolumn{2}{|l|}{ Mean $(\mathbf{P b})$} & 17.77 & 24.44 \\
\hline \multirow{3}{*}{ Mean (MA) } & 0 & 18.45 & 25.24 \\
\hline & 250 & 19.33 & 26.28 \\
\hline & 500 & 18.91 & 25.70 \\
\hline \multirow{3}{*}{ L.S.D. at 0.05} & $\mathbf{P b}$ & 0.24 & 0.40 \\
\hline & MA & 0.47 & 0.51 \\
\hline & $\mathbf{P b} \times \mathbf{M A}$ & 0.54 & 0.58 \\
\hline
\end{tabular}

significantly produced the lowest number of flowers per plant (17.77 and 24.44) in the first and second seasons, respectively.

Flowers number per plant was also significantly affected by spraying the plants with malic acid. In both seasons, flower number increased gradually when the malic acid concentration was raised from $0 \mathrm{ppm}$ (control) to 250 ppm, in (Table 3) as Lantana camara var. Nana plants sprayed with 250 ppm malic acid significantly formed the highest number of flowers per plant (19.33 and 26.28) in the first and second seasons, respectively.

Regarding the interaction between the effects of irrigation with contaminated lead water and malic acid treatments on flowers number of Lantana camara var. Nana plants, the results in both seasons, showed that, the highest values were (20.00 and 27.16), obtained in the plants irrigated with tap water and sprayed with malic acid at $250 \mathrm{ppm}$, respectively. On the other hand, the minimum number of flowers (17.33 and 24.16) in the first and second seasons, respectively, was obtained with highest lead concentration (300 ppm) without malic acid treatment, it can also revealed that in many cases, spraying the plants with malic acid 
reduced the undesirable effect of contaminated water with lead.

\subsection{Chemical constituents}

\subsubsection{Total chlorophylls (SPAD) and}

Carbohydrates content (\% D.W)

The results presented in Table (4) showed that the highest content of total chlorophylls was obtained in plants irrigated with tap water (54.84 and 55.32 SPAD) and carbohydrates (18.64 and $18.81 \%$ D.W) in the first and the second seasons, respectively. Raising lead concentration in irrigation water resulted in steady sign

ificant reductions in the total chlorophylls and carbohydrates content, which reached its lowest values (49.43 and 50.14 SPAD) and (16.80 and $17.05 \%$ D.W) in the first and the second seasons, respectively, in plants receiving the highest lead concentration $300 \mathrm{ppm}$.

The results of leaf chemical analysis (Table 4) also showed that malic acid treatments had clear effect on the total chlorophyll and carbohydrates content. The highest contents of total chlorophyll (54.51 and 54.97 SPAD) and carbohydrates (18.53 and $18.69 \%$ D.W) in the first and the second seasons, respectively, in plants sprayed with malic acid at $500 \mathrm{ppm}$.
Regarding the interaction between the effects of irrigation using water contaminated with lead and malic acid treatments, the data presented in Table (4) showed that the highest total chlorophylls contents (56.50 and 56.87 SPAD) and carbohydrates (19.21 and $19.34 \%$ D.W) in the first and the second seasons, respectively, were found in leaves of plants irrigated with tap water and sprayed with malic acid at $500 \mathrm{ppm}$ and the corresponding lowest values (46.70 and 47.73 SPAD) and (15.88 and $16.23 \%$ D.W) were obtained with lead at 300 ppm without malic acid treatment.

\subsubsection{Lead content in leaves, stems and roots (ppm)}

Data in Table (4) showed that lead content in the dried leaves of Lantana camara var. Nana plants increased steadily with increasing lead concentration in irrigation water. The lowest lead content in leaves (0.536 and $1.035 \mathrm{ppm})$, in stem $(1.525$ and $2.024 \mathrm{ppm})$ and in root $(0.785$ and $1.054 \mathrm{ppm})$ in the first and second seasons, respectively, were found in control plants, whereas the corresponding highest values in leaves (3.088 and $3.613 \mathrm{ppm}$ ), in stem (4.103 and $4.625 \mathrm{ppm})$ and in root (2.114 and 2.383

Table (4): Means of chemical constituents characteristics of Lantana camara var. Nana plants as influenced by lead (Pb), Malic acid (MA) and their combinations (Pb $\times$ MA) in the two seasons of 2017 and 2018.

\begin{tabular}{|c|c|c|c|c|c|c|c|c|c|c|c|}
\hline \multicolumn{2}{|c|}{ Treatments } & \multicolumn{2}{|c|}{$\begin{array}{c}\text { Chlorophyll } \\
\text { content } \\
\text { (SPAD) }\end{array}$} & \multicolumn{2}{|c|}{$\begin{array}{c}\text { Carbohydrates } \\
\text { content } \\
(\%)\end{array}$} & \multicolumn{2}{|c|}{$\begin{array}{c}\text { Lead content in } \\
\text { leaves } \\
\text { (ppm) }\end{array}$} & \multicolumn{2}{|c|}{$\begin{array}{c}\text { Lead content in } \\
\text { stem } \\
(\mathbf{p p m}) \\
\end{array}$} & \multicolumn{2}{|c|}{$\begin{array}{l}\text { Lead content in } \\
\text { roots }(\mathrm{ppm})\end{array}$} \\
\hline Lead (ppm) & $\begin{array}{l}\text { Milk } \\
\text { acid } \\
\text { (ppm) }\end{array}$ & 2017 & 2018 & 2017 & 2018 & 2017 & 2018 & 2017 & 2018 & 2017 & 2018 \\
\hline \multirow{3}{*}{000} & 0 & 53.18 & 53.89 & 18.08 & 18.32 & 0.783 & 1.309 & 1.797 & 2.253 & 0.926 & 1.195 \\
\hline & 250 & 54.85 & 55.21 & 18.65 & 18.77 & 0.517 & 1.041 & 1.532 & 2.053 & 0.789 & 1.058 \\
\hline & 500 & 56.50 & 56.87 & 19.21 & 19.34 & 0.309 & 0.756 & 1.247 & 1.768 & 0.642 & 0.911 \\
\hline \multicolumn{2}{|l|}{ Mean $(\mathrm{Pb})$} & 54.84 & 55.32 & 18.64 & 18.81 & 0.536 & 1.035 & 1.525 & 2.024 & 0.785 & 1.054 \\
\hline \multirow{3}{*}{100} & 0 & 49.34 & 49.72 & 16.78 & 16.90 & 1.590 & 2.114 & 2.605 & 3.026 & 1.342 & 1.610 \\
\hline & 250 & 54.31 & 55.04 & 18.47 & 18.72 & 1.528 & 2.052 & 2.543 & 2.997 & 1.310 & 1.579 \\
\hline & 500 & 56.08 & 56.45 & 19.07 & 19.19 & 1.383 & 1.908 & 2.398 & 2.885 & 1.235 & 1.504 \\
\hline \multicolumn{2}{|l|}{ Mean (Pb) } & 53.24 & 53.73 & 18.10 & 18.27 & 1.500 & 2.024 & 2.515 & 2.969 & 1.295 & 1.054 \\
\hline \multirow{3}{*}{200} & 0 & 47.74 & 48.75 & 16.23 & 16.58 & 2.830 & 2.821 & 3.845 & 3.833 & 1.981 & 1.975 \\
\hline & 250 & 52.75 & 53.12 & 17.94 & 18.06 & 2.721 & 2.712 & 3.736 & 3.724 & 1.925 & 1.919 \\
\hline & 500 & 53.66 & 54.05 & 18.24 & 18.38 & 2.656 & 2.677 & 3.668 & 3.689 & 1.890 & 1.901 \\
\hline \multicolumn{2}{|l|}{ Mean $(\mathrm{Pb})$} & 51.38 & 51.97 & 17.47 & 17.67 & 2.735 & 2.736 & 3.749 & 3.748 & 1.932 & 1.931 \\
\hline \multirow{3}{*}{300} & 0 & 46.70 & 47.73 & 15.88 & 16.23 & 3.192 & 3.717 & 4.207 & 4.728 & 2.167 & 2.437 \\
\hline & 250 & 49.78 & 50.16 & 16.92 & 17.06 & 3.042 & 3.566 & 4.057 & 4.578 & 2.090 & 2.359 \\
\hline & 500 & 51.83 & 52.53 & 17.62 & 17.86 & 3.032 & 3.557 & 4.047 & 4.569 & 2.086 & 2.354 \\
\hline \multicolumn{2}{|l|}{ Mean (Pb) } & 49.43 & 50.14 & 16.80 & 17.05 & 3.088 & 3.613 & 4.103 & 4.625 & 2.114 & 2.383 \\
\hline \multirow{3}{*}{ Mean (MA) } & 0 & 49.24 & 50.02 & 16.74 & 17.00 & 2.098 & 2.490 & 3.113 & 3.460 & 1.604 & 1.804 \\
\hline & 250 & 52.92 & 53.38 & 17.99 & 18.15 & 1.952 & 2.342 & 2.967 & 3.338 & 1.528 & 1.728 \\
\hline & 500 & 54.51 & 54.97 & 18.53 & 18.69 & 1.845 & 2.224 & 2.840 & 3.227 & 1.463 & 1.667 \\
\hline \multirow{3}{*}{$\begin{array}{l}\text { L.S.D. at } \\
0.05\end{array}$} & $\mathbf{P b}$ & 0.51 & 0.49 & 0.17 & 0.17 & 0.310 & 0.292 & 0.286 & 0.253 & 0.147 & 0.150 \\
\hline & MA & 0.38 & 0.37 & 0.13 & 0.12 & 0.313 & 0.287 & 0.330 & 0.260 & 0.170 & 0.148 \\
\hline & $\mathbf{P b} \times \mathbf{M A}$ & 0.44 & 0.43 & 0.15 & 0.14 & 0.360 & 0.329 & 0.378 & 0.308 & 0.195 & 0.169 \\
\hline
\end{tabular}


ppm) were recorded in the plants irrigated with the highest lead concentration $300 \mathrm{ppm}$.

Concerning the effect of malic acid treatments on lead content in leaves, the data recorded in the two seasons (Table 4) showed the high level of malic acid (500 ppm) was the only treatment that caused a significant decrease in lead content in leaves (1.845 and $2.224 \mathrm{ppm}$ ), in stems (2.840 and $3.227 \mathrm{ppm})$ and in roots (1.463 and $1.667 \mathrm{ppm})$ in the first and the second seasons, respectively, compared to that of control plants with the highest lead content in leaves (2.098 and $2.490 \mathrm{ppm})$, in stems (3.113 and $3.460 \mathrm{ppm})$ and in root (1.604 and 1.804 $\mathrm{ppm})$ in the first and the second seasons, respectively.

Concerning the interaction between the effects of irrigation using water contaminated with lead and malic acid treatments on lead content in different plant parts, the results in (Table 4) showed that the lowest values of lead content in leaves (0.309 and $0.756 \mathrm{ppm})$, in stems (1.247 and $1.768 \mathrm{ppm})$ and in root $(0.642$ and $0.911 \mathrm{ppm})$ in the first and the second seasons, respectively, were obtained in the plants irrigated with tap water and sprayed with malic acid at $500 \mathrm{ppm}$. On the other hand, the highest lead content in the plant parts were obtained with the treatment of lead at $300 \mathrm{ppm}$ without malic acid application giving (3.192 and 3.717 ppm), in stems (4.207 and $4.728 \mathrm{ppm}$ ) and in roots (2.167 and $2.437 \mathrm{ppm})$.

Table (5): Average of lead content in soil samples as influenced by lead concentration in water irrigation and foliar application of malic acid on Lantana camara var. Nana in the two seasons of 2017 and 2018.

\begin{tabular}{|c|c|c|c|}
\hline \multicolumn{2}{|c|}{ Treatments } & \multirow{2}{*}{\multicolumn{2}{|c|}{$\begin{array}{l}\text { Lead content in soil } \\
(\text { ppm) }\end{array}$}} \\
\hline \multirow{2}{*}{$\begin{array}{c}\text { Lead } \\
(\mathrm{ppm})\end{array}$} & \multirow{2}{*}{$\begin{array}{c}\text { Malic } \\
\text { acid } \\
\text { (ppm) }\end{array}$} & & \\
\hline & & 2017 & 2018 \\
\hline \multirow{3}{*}{$\mathbf{0}$} & $\mathbf{0}$ & 0.435 & 0.492 \\
\hline & 250 & 0.361 & 0.419 \\
\hline & 500 & 0.280 & 0.341 \\
\hline \multirow{3}{*}{100} & $\mathbf{0}$ & 0.935 & 0.994 \\
\hline & 250 & 0.887 & 0.956 \\
\hline & 500 & 0.868 & 0.927 \\
\hline \multirow{3}{*}{200} & $\mathbf{0}$ & 1.695 & 1.754 \\
\hline & 250 & 1.545 & 1.624 \\
\hline & 500 & 1.446 & 1.505 \\
\hline \multirow{3}{*}{300} & $\mathbf{0}$ & 2.194 & 2.253 \\
\hline & 250 & 2.123 & 2.192 \\
\hline & 500 & 2.064 & 2.123 \\
\hline
\end{tabular}

\subsection{Transfer factor (TF) of lead}

Transfer factor (TF) indicates the efficiency of plants to transfer metals from root to the aerial parts, which is calculated as the ratio between metal concentration in different plant parts to the metal concentration in the soil (Chen et al., 2004).

\subsubsection{Lead content in soil samples (ppm)}

Data in Table (5) showed that the lowest average of lead content was observed in the soil cultured by untreated plants, while the highest average of lead content was observed in the soil after the treatment $300 \mathrm{ppm}$ lead and $0 \mathrm{ppm}$ malic acid.

\subsubsection{Transfer factors}

From the data presented in Table (6), it can be seen that the transfer factor in the different dried plant parts of Lantana camara var. Nana was decreased steadily with raising lead concentration in irrigation water. Accordingly, the lowest lead value in the leaves (1.445 and $1.655 \mathrm{ppm})$, in stem (1.929 and $2.119 \mathrm{ppm})$ and in root $(0.993$ and $1.091 \mathrm{ppm})$ was found in plants irrigated with water containing lead concentration $300 \mathrm{ppm}$, whereas the highest value in leaves (1.755 and $2.453 \mathrm{ppm})$, in stem (4.275 and $4.887 \mathrm{ppm})$ and in root (2.201 and $2.541 \mathrm{ppm}$ ) was found in plants irrigated with tap water (control). So, the transfer factor in the dried plant parts (Table 6) was reduced steadily with raising malic acid concentration. Accordingly, the highest lead value in the leaves (1.665 and $2.010 \mathrm{ppm})$, in stems (2.775 and $2.976 \mathrm{ppm})$ and in roots (1.429 and $1.563 \mathrm{ppm})$ was recorded in the leaves of control plants, whereas plants sprayed with the highest malic acid concentration $500 \mathrm{ppm}$ had the lowest lead value in the leaves (1.500 and $1.932 \mathrm{ppm})$, in stems (2.927 and $3.224 \mathrm{ppm})$ and in roots (1.507 and $1.666 \mathrm{ppm})$.

\section{DISCUSSION}

This study revealed that at high heavy-metal concentrations, the plant height was significantly reduced, and the biomass was decreased. The root growth was more sensitive than other parameters, as roots rapidly absorbed water and had higher accumulations of heavy metal elements. The results presented in this study were in agreement with earlier reports on other plants, such as aquatic plant wolffia arrhiza (Piotrowska et al., 2010), barley Hordeum vulgare (Tiryakioglu et al., 2006) and Typha 
Table (6): Means of transfer factor to leaves, stem and roots of Lantana camara var. Nana plants as influenced by lead (Pb), Malic acid (MA) and their combinations $(\mathrm{Pb} \times \mathrm{MA})$ in the two seasons of 2017 and 2018.

\begin{tabular}{|c|c|c|c|c|c|c|c|}
\hline \multicolumn{2}{|c|}{ Treatments } & \multirow{2}{*}{\multicolumn{2}{|c|}{$\begin{array}{c}\text { Transfer } \\
\text { factor to leaves } \\
\text { (TFL) }\end{array}$}} & \multirow{2}{*}{\multicolumn{2}{|c|}{$\begin{array}{c}\text { Transfer factor to } \\
\text { stem } \\
\text { (TFS) } \\
\end{array}$}} & \multirow{2}{*}{\multicolumn{2}{|c|}{$\begin{array}{c}\text { Transfer factor to } \\
\text { root } \\
\text { (TFR) } \\
\end{array}$}} \\
\hline \multirow{2}{*}{$\begin{array}{c}\text { Lead } \\
(\mathrm{ppm})\end{array}$} & \multirow{2}{*}{$\begin{array}{c}\text { Malic } \\
\text { acid } \\
\text { (ppm) }\end{array}$} & & & & & & \\
\hline & & 2017 & 2018 & 2017 & 2018 & 2017 & 2018 \\
\hline \multirow{3}{*}{000} & 0 & 1.669 & 2.660 & 4.131 & 4.579 & 2.128 & 2.428 \\
\hline & 250 & 1.761 & 2.484 & 4.243 & 4.899 & 2.185 & 2.525 \\
\hline & 500 & 1.836 & 2.217 & 4.453 & 5.184 & 2.292 & 2.671 \\
\hline \multicolumn{2}{|c|}{ Mean $(\mathbf{P b})$} & 1.755 & 2.453 & 4.275 & 4.887 & 2.201 & 2.541 \\
\hline \multirow{3}{*}{100} & 0 & 1.700 & 2.126 & 2.786 & 3.044 & 1.435 & 1.619 \\
\hline & 250 & 1.722 & 2.169 & 2.866 & 3.168 & 1.476 & 1.669 \\
\hline & 500 & 1.593 & 2.058 & 2.762 & 3.112 & 1.422 & 1.622 \\
\hline \multicolumn{2}{|c|}{ Mean $(\mathrm{Pb})$} & 1.671 & 2.117 & 2.804 & 3.108 & 1.444 & 1.636 \\
\hline \multirow{3}{*}{200} & 0 & 1.454 & 1.608 & 2.268 & 2.185 & 1.168 & 1.125 \\
\hline & 250 & 1.432 & 1.690 & 2.418 & 2.321 & 1.245 & 1.196 \\
\hline & 500 & 1.468 & 1.778 & 2.536 & 2.451 & 1.307 & 1.263 \\
\hline \multicolumn{2}{|c|}{ Mean $(\mathrm{Pb})$} & 1.451 & 1.692 & 2.407 & 2.319 & 1.240 & 1.194 \\
\hline \multirow{3}{*}{300} & 0 & 1.800 & 1.649 & 1.917 & 2.098 & 0.987 & 1.081 \\
\hline & 250 & 1.432 & 1.641 & 1.910 & 2.107 & 0.984 & 1.086 \\
\hline & 500 & 1.103 & 1.675 & 1.9607 & 2.152 & 1.010 & 1.108 \\
\hline \multicolumn{2}{|c|}{ Mean $(\mathbf{P b})$} & 1.445 & 1.655 & 1.929 & 2.119 & 0.993 & 1.091 \\
\hline \multirow{3}{*}{$\begin{array}{l}\text { Mean } \\
\text { (MA) }\end{array}$} & 0 & 1.655 & 2.010 & 2.775 & 2.976 & 1.429 & 1.563 \\
\hline & 250 & 1.586 & 1.996 & 2.859 & 3.123 & 1.472 & 1.619 \\
\hline & 500 & 1.500 & 1.932 & 2.927 & 3.224 & 1.507 & 1.666 \\
\hline
\end{tabular}

angustifolia (Bah et al., 2011). Other studies with woody plant reported a high inhibition of root elongation (Dominguez et al., 2009). In particular, Jatropha plants could bioaccumulate and bioconcentrate toxic heavy metals from an aqueous solution (Mohammad et al., 2010) and could be used as phytoremediation candidates in some countries (Juwarkar et al., 2008; Kumar et al., 2008 and Jamil et al., 2009). Additionally, the plant seedlings exhibited a high root/shoot ratio. An alternative explanation might relate to a strong root system with many roots spread out over the entire soil for survival because root/shoot ratio could reflect plant's response to various environment factors (Otieno et al., 2005; Lukacova and Lux, 2010 and Li et al., 2010).

Plants can tolerate lead either by external exclusion or internal tolerance. By the external exclusion, lead ions are excluded from entering the plant cells and thus lead cannot accumulate in the organelles and excess lead ions are removed out of the plant cell (Sharma and Dubey 2005). The internal tolerance of lead is mainly due to the synthesis of organic lead compounds (cysteine, glutathione, phytochelatin, etc) and eventually lead ions are transformed in the cell into chemically bound structures with lower toxicity, alleviating the $\mathrm{Pb}$ toxic effect on the plants tissues (Pourrut et al., 2011). Lead can damage the ultrastructures of the organs, tissues, chloroplast, mitochondria, nucleus, cell wall, and cell membrane in the plants. This damage can cause a loss of organelle function, and can eventually affect the normal physiological functions that include photosynthesis, respiration, protein synthesis, cell division within the plant species (Salazar and Pignata, 2014).

Concerning the treatments and the control samples, at a preliminary stage, one should note that the transfer factor of most treatments is lower than one for lead; which means that the physiological need of the plant for these elements is rather limited.

In malic acid, while there were no significant differences between the applied concentrations, but in the root, fresh weight, and root dry weight, we see that only the higher concentration is considered significantly different from the control. When comparing with earlier reports, here we observe more similarity between responses of selected traits to organic acids. In some traits, the lower concentration gave good results that give us the idea of 
possible distinct patterns of response to concentration of applied organic acids. Therefore, we suggest testing both lower and higher concentrations of these organic acids to reach a better understanding in this regard (Talebi et al., 2014). Malic acid spray increased chlorophyll content significantly. Chlorophyll content was the highest in plants treated with malic acid alone with SPAD reading compared with the control. All factor-levels containing malic acid had significantly higher chlorophyll content compared with the control (Darandeh and Hadavi, 2012).

\section{Conclusions}

The concentrations of heavy metals increase in the environment from year to year. Therefore decontamination of heavy metal-contaminated water and soils is very important for maintenance of environmental health and ecological restoration. Phytoremediation is a new cleanup concept that involves the use of plants to clean or stabilize contaminated environments. Phytoremediation of metals is the most effective plant-based method to remove pollutants from the contaminated areas. This green technology can be applied to remediate the polluted soils without creating any destructive effect of soil structure or parameters. Some specific plants, such as woody species, have been proven to have noticeable potential to absorb toxic heavy metals.

Phytoremediation of contaminated water and soil with heavy metals using non-edible plant like Lantana camara var. Nana offers an environmental friendly and cost-effective method for remediating the polluted soil. Lantana camara var. Nana was found to be able to efficiently remove the heavy metals such as lead.

\section{REFERENCES}

Ashwini A., Swati K. and Sujata G. (2014). Evaluation of phytoremediation potential of Lantana camara for heavy metals in an industrially polluted area in Bhopal, India. Inter`1 J. Eng.and Appl. Sci., 1 (2): 1-3.

Bah A.M., Dai H., Zhao J., Sun H., Cao F., Zhang G. and Wu F. (2011). Effects of lead, chromium and lead on growth, metal uptake and antioxidative capacity in Typha angustifolia. Biol. Trace Elem. Res., 142: 77-92.

Chen Y., Shen Z. and Li X. (2004). The use of vetiver grass (Vetiveria zizanioides) in the phytoremediation of soils contaminated with heavy metals. Appli. Geochem. 19: 1553-1565.

Dakora F.D. and Phillips D.A. (2002). Root exudates as mediators of mineral acquisition in low-nutrient environments. Plant Soil., 245, 35-47.

Darandeh N. and Hadavi E. (2012). Effect of pre-harvest foliar application of citric acid and malic acid on chlorophyll content and post-harvest vase life of Lilium cv. Brunello. Front. in Plant Sci.: Crop Sci. and Horti., 2(106): 1-3.

Dominguez M.T., Madrid F., Maranon T. and Murillo J.M. (2009). Lead availability in soil and retention in oak roots: potential for phytostabilization. Chemosphere, 76 : 480-486.

Dubios M., Gilles K., Hamlton J., Rebers P. and Smith F. (1956). Colourimetric method for determination of sugars and related substances. Analyt. Chem., 28(3): 350356.

Jackson N. L. (1958). Soil Chemical Analysis.Constable. Ltd. Co., London, $498 \mathrm{p}$.

Jamil S., Abhilash P.C., Singh N. and Sharma P.N. (2009). Jatropha curcas: a potential crop for phytoremediation of coal fly ash. J. Hazard. Mater., 172: 269-275.

Jones D. L. (1998). Organic acids in the rhizosphere a critical review. Plant Soil., 205, 25-44.

Juwarkar A.A., Yadav S.K., Kumar P. and Singh S.K. (2008). Effect of biosludge and biofertilizer amendment on growth of Jatropha curcas in heavy metal contaminated soils. Environ. Monit. Assess., 145: 7-15.

Koller H.R. (1972). Leaf area, leaf weight relationship in the soybean canopy. Crop Sci., 12: 180-183.

Kumar G.P., Yadav S.K., Thawale P.R., Singh S.K. and Juwarkar A.A. (2008). Growth of Jatropha curcas on heavy metal contaminated soil amended with industrial wastes and Azotobacter. A greenhouse study. Bioresour. Technol., 99: 2078-2082.

Li X., Shen X., Li J., Eneji A.E., Li Z., Tian X. and Duan L. (2010). Coronatine alleviates water deficiency stress on winter wheat seedlings. J. Integr. Plant Biol., 52: 616-625. 
Lindsay W.L. and Norvell W.A. (1978). Development of a DTPA soil test for zinc, iron, manganese and copper. Soil Sci. Soc. Am. J., 42: 421-428.

Lukacova K. Z. and Lux A. (2010). Silicon influence on maize, Zea mays L., hybrids exposed to lead treatment. Bull. Environ. Contam. Toxicol., 85: 243-250.

Mahler R.J., Bingham F.T. and Chang A.C. (1981). Effect of heavy metal pollution on plants. Appl. Sci., 1:72-109.

Mohammad M., Maitra S., Ahmad N., Bustam A., Sen T.K. and Dutta B.K. (2010). Metal ion removal from aqueous solution using physic seed hull. J. Hazard. Mater., 179: 363-372.

Otieno D.O., Schmidt M.W., Adiku S. and Tenhunen J. (2005). Physiological and morphological responses to water stress in two Acacia species from contrasting habitats. Tree Physiol., 25: 361-371.

Piotrowska A., Bajguz A., GodlewskaZylkiewicz B. and Zambrzycka E. (2010). Changes in growth, biochemical components, and antioxidant activity in aquatic plant Wolffiaarrhiza(Lemnaceae) exposed to cadmium and lead. Arch. Environ. Contam. Toxicol., 58: 594-604.

Piper O.S. (1947). Soil and plant Analysis. Adelaite University, Adelaide, Australia , 258-275.

Pourrut B., Shahid M., Dumat C., Winterton P. and Pinelli E. (2011). Lead uptake, toxicity, and detoxification in plants. Rev. Environ. Contam, 213:113-136.

Salazar M.J. and Pignata M.L. (2014). Lead accumulation in plants grown in polluted soils. Screening of native species for phytoremediation. J. Geochem. Explor., 137:29-36.

SAS Institute (2002). SAS User Guide and Program 20 Version 9.0.38. Cary, North Carolina, USA.

Sharma B.D., Mukhopadhyay S.S. and Katyal J.C. (2006). Distribution of total and DTPA- extractable zinc, copper, manganese and iron in vertisols of India. Com. Soil Sci. Plant Anal., 37: 653-672.

Sharma P. and Dubey R.S. (2005). Lead toxicity in plants. B. J. Plant Physiol., 17:35-52.

Snedecor G.W. and Cochran W.(1989). Statistical Methods, $8^{\text {th }}$ ed. Edition, Iowa State University Press. Ames. Iowa. USA.

Talebi M, Hadavi E. and Jaafari N. (2014). Foliar sprays of citric acid and malic acid modify growth, flowering, and root to shoot ratio of gazania (Gazania rigens L.). Adv. Agric. Article ID 147278, 1-6.

Tiryakioglu M., Eker S., Ozkutlu F., Husted S. and Cakmak I. (2006). Antioxidant defense system and lead uptake in barley genotypes differing in lead tolerance. J. Trace Elem. Med. Biol., 20: 181-189.

Unhalekhana U., and Kositanont C. (2008). Distribution of lead in soil around zinc mining area. Thai J. of Toxico., 23:170174.

Wua G., Kanga H., Zhangc X., Shaob H., Chuc L. and Ruand C. (2010). A critical review on the bio-removal of hazardous heavy metals from contaminated soils: Issues, progress, eco-environmental concerns and opportunities. J. Haz. Mat., 174: 1-8.

Yadava U. (1986). A rapid and nondestructive method to determine chlorophyll in intact leaves. Hort. Sci., 21(6): 1449-1450. 


\author{
إستجابة نباتات اللانتانا للرش بحمض الماليك لتقليل الأثر الضار للتلوث بالرصاص فى ماء الرى \\ نادر أحمد الثنهورى ـ أسماء محمد طه* ـ مجد الدين فؤاد رضا*

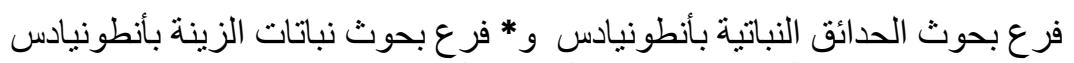

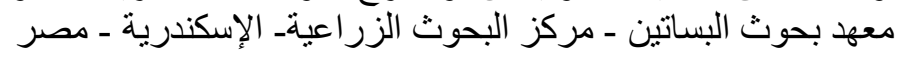

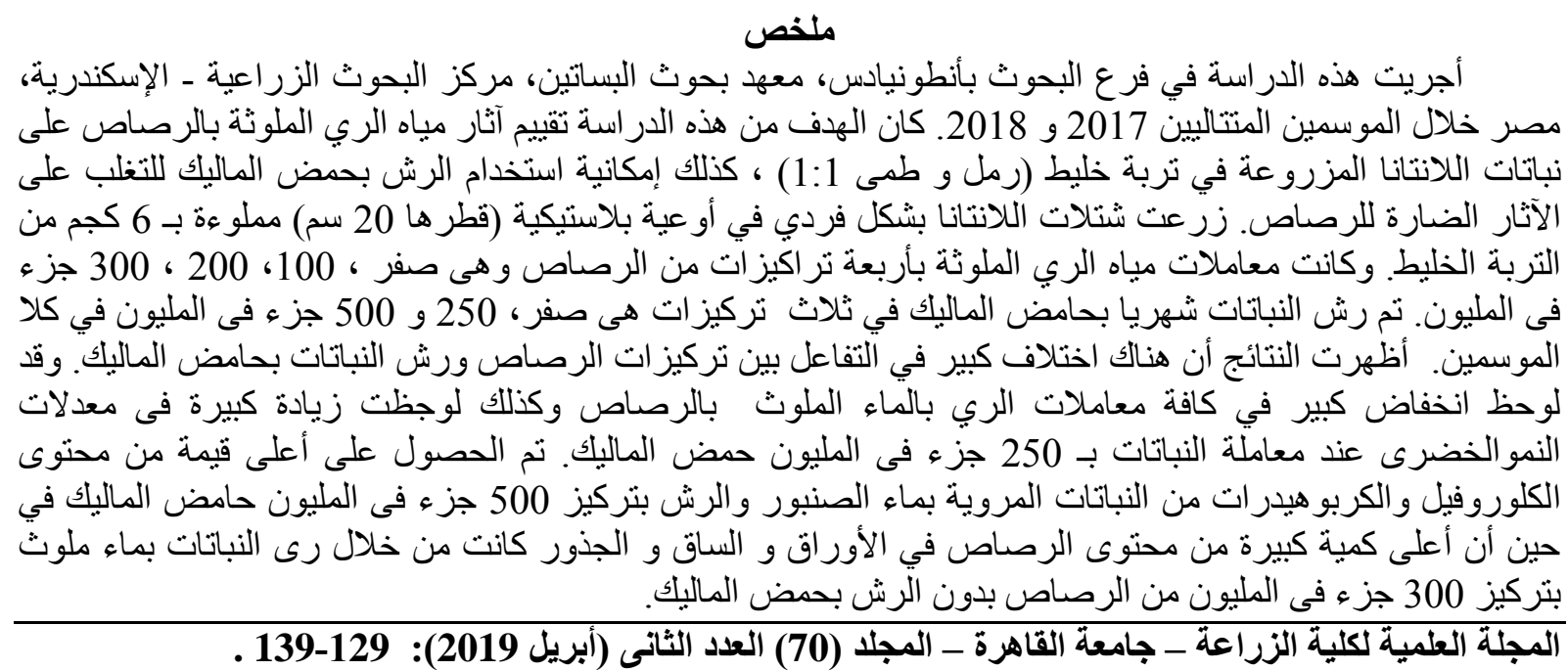

